\title{
THE HYDROMAGNESITE DEPOSITS OF THE ATLIN AREA, BRITISH COLUMBIA, CANADA, AND THEIR INDUSTRIAL POTENTIAL AS A FIRE RETARDANT
}

\section{Stamatakis M. G. ${ }^{1}$, Renaut R. W. ${ }^{2}$, Kostakis K. ${ }^{1}$, Tsivilis S. $^{3}$, Stamatakis G. ${ }^{4}$, and Kakali G. ${ }^{3}$}

${ }^{1}$ National \& Kapodistrian University of Athens, Dept. of Geology \& Geoenvironment, Panepistimiopolis, Ano Ilissia15784 Athens, Greece, stamatakis@geol.uoa.gr

${ }^{2}$ Dept. of Geological Sciences, University of Saskatchewan, Saskatoon SK, S7N 5E2, Canada

${ }^{3}$ National Technical University of Athens, Dept. of Chemical Engineering, 9 Heroon Polytechniou str., 15773 Zografou, Athens, Greece

${ }^{4}$ National \& Kapodistrian University of Athens, Dept. of Chemistry, Panepistimiopolis, Ano Ilissia 15784 Athens, Greece

\begin{abstract}
This research examines the potential of the hydromagnesite deposits at Atlin in British Columbia, Canada, for the mineral fire-retardant market. Mineral fire retardants, such as $\mathrm{Mg}$ - and $\mathrm{Ca} / \mathrm{Mg}$-carbonates, are environmentally friendly, producing non-toxic and non-corrosive gases during their thermal decomposition. During this research, 70 sediment samples and two bulk samples were collected from the study area and analysed. The results showed that the Atlin deposits are composed mostly of hydromagnesite with minor amounts of very fine-grained, soft and platy magnesite. The general conclusion is that the mineralogical composition of the samples, their behaviour during thermal decomposition, and their chemical and physical properties, make them suitable for use as white fillers for flame-retardants. Additionally, the whiteness of the samples is sufficient and comparable to other commercial hydromagnesite-bearing rocks. The Atlin reserves of the hydromagnesite ore bodies were overestimated in past literature as 110,000 tons. A more precise calculation of the reserves during a technoeconomic assessment is required.
\end{abstract}

Key words: Hydromagnesite, magnesite, playa, lacustrine flame retardant, white filler.

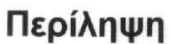

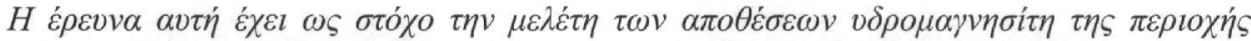

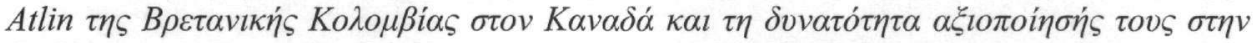

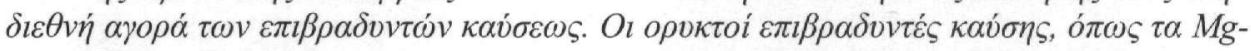

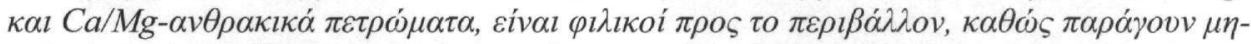

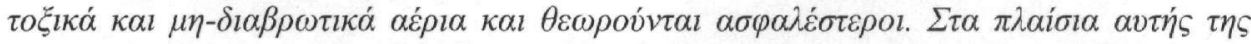

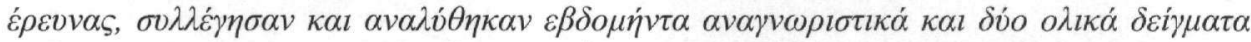

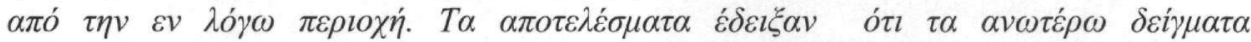

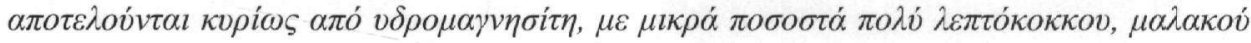




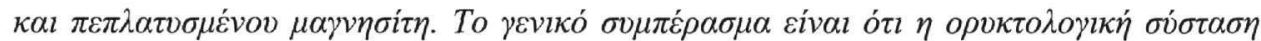

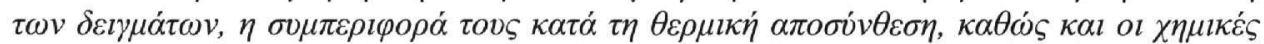

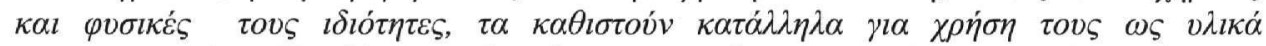

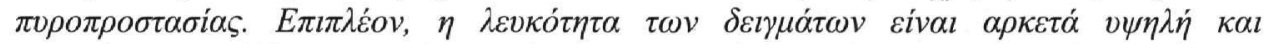

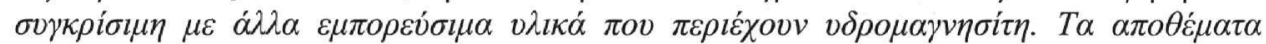

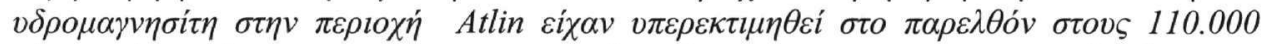

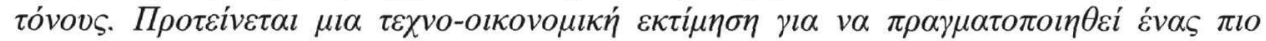

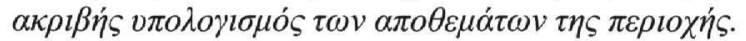

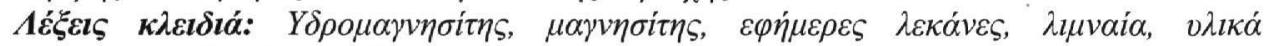

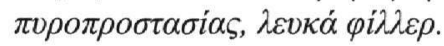

\section{Introduction}

Household furnishings usually contain highly flammable plastic polymers. During manufacture, fire retardants are added to these polymers to reduce their flammability and the amount of heat produced during combustion. Due to a number of "Health \& Safety" and environmental concerns, the industrial demand for safe, natural mineral substitutes to replace toxic, corrosive synthetic fire retardants is increasing (Loughbrough 1991, Clarke 1993, O'Driscoll 1994). The function of a fire retardant is to reduce the flammability of the polymer and to act as heat sink. Synthetic fire retardants have several adverse, possibly life-threatening, environmental effects as they produce toxic and corrosive smoke during combustion. In contrast, mineral fire retardants produce nontoxic and non-corrosive gases and are considered safer (Schmidt 1998). The demand for mineral fire-retardants has increased appreciably in EU countries as a result of more stringent legislation related to fire hazards and smoke inhalation. Jackson and Rothon (1991) and Rothon (1994) identified certain mineral hydrates and carbonates as having a good level of flame retardancy. The principal types of mineral fire retardants are metal hydroxides, including aluminium trihydrate $\left[\mathrm{Al}(\mathrm{OH})_{3}\right]$ known also as $\mathrm{ATH}$, brucite $\left[\mathrm{Mg}(\mathrm{OH})_{2}\right]$, and carbonates, including nesquehonite $\left[\mathrm{MgCO}_{3} \cdot 3 \mathrm{H}_{2} \mathrm{O}\right]$, hydromagnesite $\left[\mathrm{Mg}_{5}\left(\mathrm{CO}_{3}\right)_{4}(\mathrm{OH})_{2} \cdot 4 \mathrm{H}_{2} \mathrm{O}\right]$, and huntite $\left[\mathrm{Mg}_{3} \mathrm{Ca}\left(\mathrm{CO}_{3}\right)\right]$ (Ashley and Rothon 1991). Hydromagnesite in particular, with its unusual behaviour during thermal decomposition, small grain size, platy morphology and high whiteness, can be considered an important new industrial mineral with multi-functional applications and a trend towards increased consumption, especially in the flame retardant market (Kirschbaum 1999).

On a global scale, economically significant deposits of hydromagnesite are very scarce. Skillen (1993) considers that the Neogene deposits of the Kozani Basin, Greece, are the world's only commercially significant huntite-hydromagnesite deposit (Stamatakis 1995). However, MINELCO SA has recently discovered good reserves of hydromagnesite in Turkey (S. Chatziniokolaou, personal communication 2006). Hydromagnesite deposits are also present in British Columbia, Canada, in several small lakes of the Cariboo Plateau and in the Atlin area, located near the boundary with Yukon Territory, far from the other deposits (Simandl et al. 2001, Simandl 2003) (Fig. 1).

The aim of this paper is to describe and characterize the hydromagnesite deposits of the Atlin area in British Columbia, and to assess their potential for exploitation.

\section{Geological Setting}

The hydromagnesite deposits of Atlin are located close to the eastern end of Atlin village (Fig. 1).

The main deposits lie in two small depressions, termed here the North Playa lake and South Playa lake, respectively, that become marshy toward the northwest. Although unconsolidated glacial deposits surround and underlie the hydromagnesite deposits, small outcrops of the ultramafic bedrock were found in both playas (Fig. 2). 


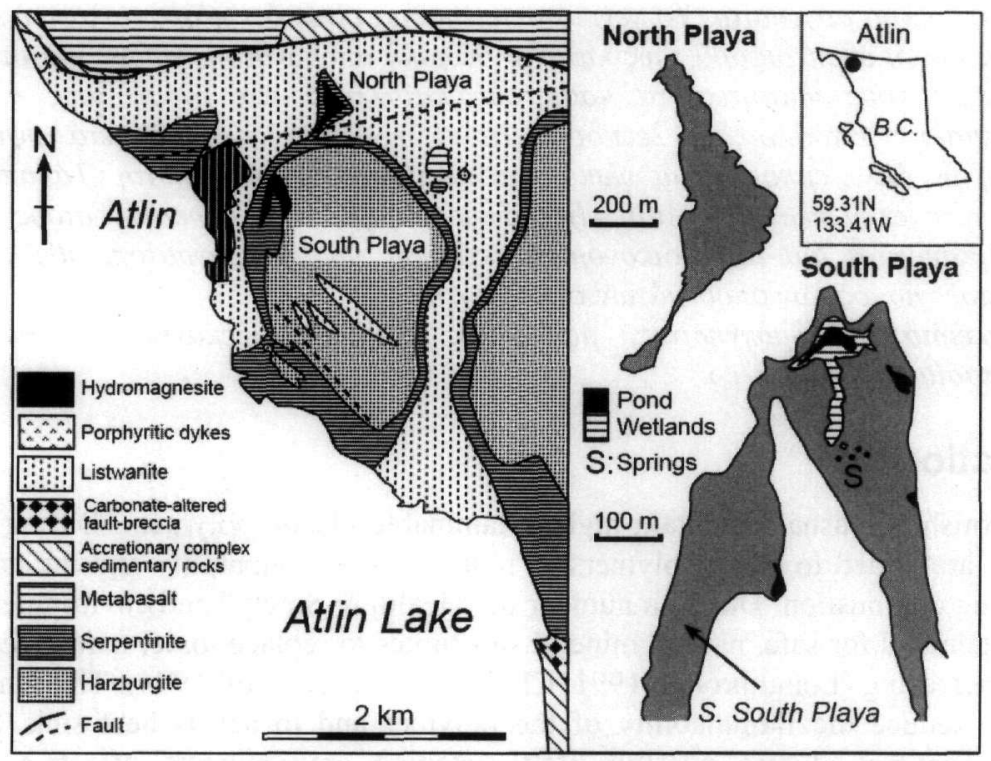

Figure 1 - Geological map of the Atlin area and the sampling sites (after Dipple 2005)

Hansen et al. (2005) recently showed that the substrate in the area is composed mainly of harzburgite, serpentinite and listwanite, which is a carbonate-altered serpentinite (Fig. 1). The hydromagnesite deposits are free of overburden, and are very fine-grained, with a bright white colour and high plasticity.

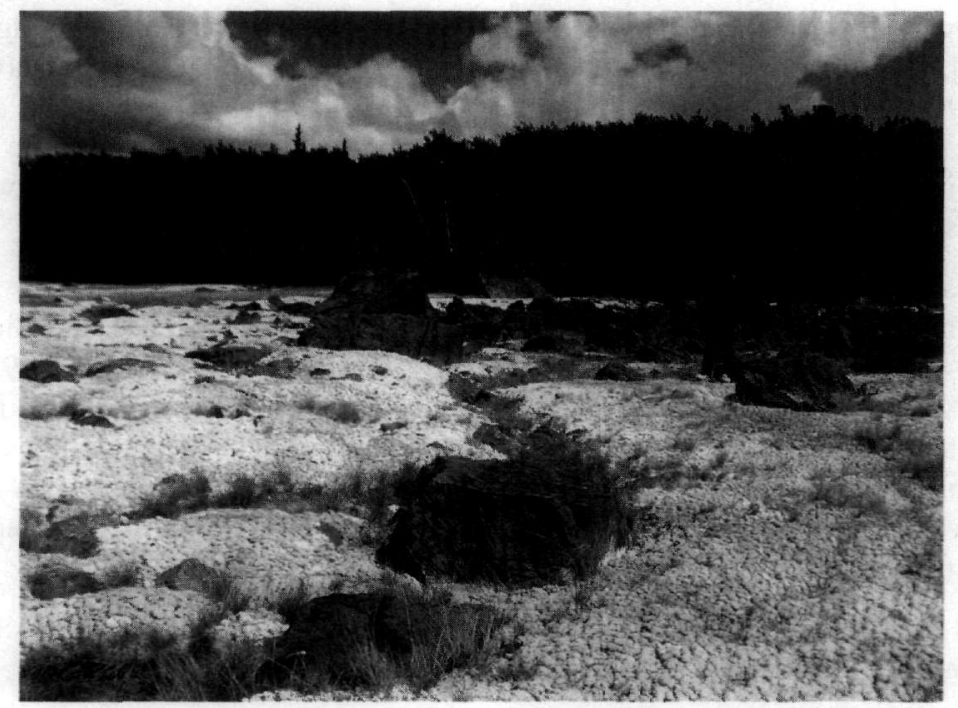

Figure 2: Weathered ultramafic rocks projecting through the white hydromagnesite sediments, eastern margin of the South Playa

\subsection{Field Work \& Rock Sampling}

Fieldwork on the Mg-rich carbonate lakes of the Atlin area was undertaken during summer, 2005. To identify the overall homogeneity of the deposits in three dimensions, 70 samples were extracted from 48 sampling sites in the North and South playas. The geometry of the lakes and the sampling sites are shown in Figure 1. 
Two additional "bulk" samples of hydromagnesite, each weighing up to $1 \mathrm{~kg}$, were shipped to the NKUA laboratories from Erana Mines Limited of Toronto, Ontario, the owners of the deposit. The samples, which were taken from the South Playa lake, were examined for their suitability as exceptionally white flame retardants.

\subsubsection{North Playa Lake}

In the North Playa lake, cauliflower-shaped mounds up to $1 \mathrm{~m}$ in diameter that are composed of smaller $(5-10 \mathrm{~cm})$ aggregates, are developed above the denser hydromagnesite-rich deposit (Fig. 3).

This feature, which is common in all the deposits at Atlin and Cariboo, is also present in the Neraida-Kozani deposits of Greece, although in the latter case, the cauliflower forms are more common in the huntite-rich mineral assemblages. Evidence of old mining and prospecting activity, such as filled-in pits, trenches, and wooden tools, was found across the North Playa. Basement material, composed of greenish to brownish clay or weakly lithified sandstone that overlies pebbles of ultramafic rocks, was found at a depth of less than $1 \mathrm{~m}$ in some of these excavations.

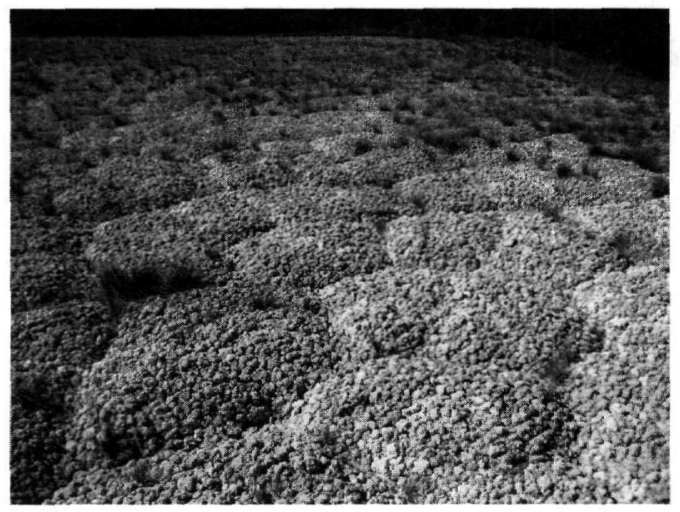

Figure 3 - Characteristic cauliflower features of the subaerially dried fine-grained hydromagnesite-magnesite, North Playa. Note the development of grass on the joins of the expanded masses, due to the entrapment of water in the small surface "channels"

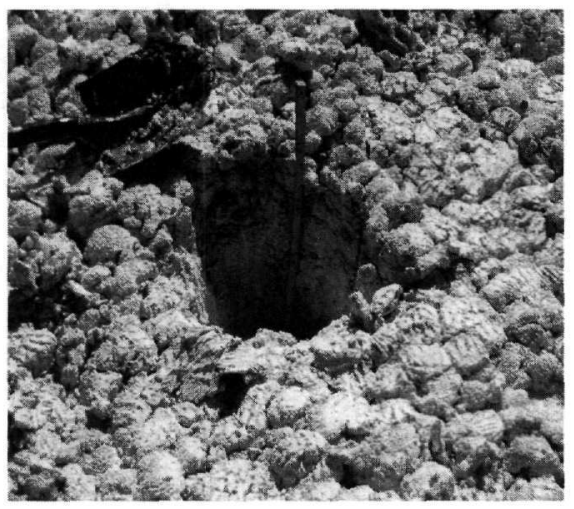

Figure 4 - Shallow pit in wet, plastic hydromagnesite in the South Playa. The hydromagnesite bed is slightly yellowish due to contamination with iron bearing substances

The hydromagnesite-rich rocks have a pinkish tint when wet, most likely because of the presence of detrital minerals and yellow-to-brownish aragonite and/or organic materials. Unlike the Kozani hydromagnesite-rich samples, which are fairly hard, the hydromagnesite from Atlin is soft and plastic when wet. Based on our XRD measurements (see below), the softness and plasticity of the samples is unaffected by the increase of magnesite. In contrast, aragonite, where present, is hard and coarse grained.

Fifteen pits were dug in the North Playa by spade, most reaching depths up to $65-70 \mathrm{~cm}$ (Fig. 4). Normally, two samples were obtained from each hole at different levels, in order to identify any stratigraphic variance in mineral content. In total, 32 samples were collected from the lake. In the southern and eastern parts of the playa, ultramafic rocks are present as hard massive boulders and closely-packed large blocks. Angular pebbles also occur in this part of the basin, as a surficial cover or as lenses a few $\mathrm{cm}$ below the surface of the deposits.

As shown by pits that reached the base of the sediments, the vertical geometry of the deposit is unpredictable. There is no caprock to preserve the entire deposit, so it is vulnerable to recent weathering and leaching. In addition, the playa substrate has an uneven topography, so the thickness of the hydromagnesite varies irregularly from $<30 \mathrm{~cm}$ to almost $2 \mathrm{~m}$. Recent weathering 
has led to the local washing-out of the finest hydromagnesite particles, leaving a yellowish aragonite residue on the surface, and staining the adjacent brownish sediments white. Old digging and reworking of the material has locally created small mounds of hydromagnesite that lie above the playa surface. This has potentially led to miscalculation of the reserves. Several hundred tons were removed before 1940 and were shipped to the USA as refractory magnesia raw materials (Aitken 1959, Grant 1987).

\subsubsection{South Playa Lake}

The South Playa Lake is composed of two elongate subbasins, partly isolated from each other by a bedrock ridge (Fig. 1). The southernmost playa, located west of the ridge, is named here the southern South Playa Lake (S-S Playa Lake). The sediments of this playa appear whiter, softer and more plastic, probably representing a more hydromagnesite-rich material than in the North Playa. In places, yellowish veins and fissure fills of containing aragonite cut the hydromagnesite deposit. The aragonitic material forms transparent sparry crystals that are mostly present on washed-out surfaces as hard residual granular material. Some 26 samples were collected from 13 sampling sites in similar manner to that of the North Playa Lake.

In the north-central part of the playa, a shallow depression is filled by wetlands and a small alkaline lake. South of lake, a group of small warm springs discharges at the playa surface. Most springs are inhabited by living microbial mats that include thick benthic mats and partly floating mats. Below the yellowish and orange mats, which are encrusted with white carbonate where subaerial exposed, lies a dark purple organic-rich substrate. Many mats show coniform and reticulate structures analogous to those produced by Phormidium (cf. Jones et al. 2002). Samples of mat were collected for examination.

Around the margins of some springs, patches of pale brown and purplish travertine a few dm thick are evidence of older spring activity. Samples were taken to identify the mineralogy of the carbonate and the iron and trace element content that may give the rock its colour.

In the northern and eastern part of the lake, ultramafic rock is present as hard massive boulders and closely-packed large blocks. Angular gravels also occur in this part of the basin, as a surficial cover or stringers a few $\mathrm{cm}$ below the surface.

\subsubsection{S-South Playa Lake}

This lake, an extension of the South Playa, has similar characteristics, including the development of travertine and tufa, local aragonite veins, and the strong plasticity of the white hydromagnesite. Fourteen sites were sample from this subbasin. The thickness of the white carbonates in this subbasin is probably greater than that of the Northern Playa. Ultramafic rocks, which are mainly harzburgite, serpentinite and listwanite, are exposed in the southeastern part of the lake, forming small hills and the linear ridge that divides the South Playa Lake from the SS Playa Lake.

\section{Experimental methods}

All sediment samples were dried at $60^{\circ} \mathrm{C}$. The 70 reconnaissance samples were exceptionally wet due to the collecting period (late June) and the high level of the groundwater at most sampling sites. Part of each sample was ground and milled to perform mineralogical and chemical analyses on powdered samples. X-ray diffraction (XRD) analysis was undertaken using a Siemens 5000 diffractometer, using standards with variable hydromagnesite/magnesite content. The prepared XRD standards used contained 5, 15, 25, 50 and $100 \%$ magnesite, the rest being hydromagnesite. The whiteness of the samples was also measured on powdered samples using the Spectro-Color whitemeter instrument [NKUA]. In addition, small chips of the "bulk" samples were coated by carbon and/or gold, then examined by scanning electron microscope [SEM: JEOL-JSM5600 equipped with Oxford Link ISIS300 EDS, NKUA] to determine the shape and size of the component microcrystals. Grain size analysis was also performed on raw samples using a laser granulometer [TITAN SA]. DTA-TG analysis was performed by the STA409 NETZCSH 
instrument [TITAN SA]. The chemistry of Atlin spring waters was determined at the University of Saskatchewan.

\section{Analytical results and interpretation}

\subsection{Mineralogical analysis (X-ray diffraction)}

For better evaluation of the carbonate mineral content, reference samples were made by mixing of pure hydromagnesite [hydromagnesite nuggets of Aliakmon River, Kozani] and magnesite [Ag. Marina, Kozani]. XRD analysis showed that almost all samples have the same mineralogy, and are composed of almost exclusively of two varieties of hydromagnesite and variable (but minor) amounts of magnesite (Fig. 5). Commonly the magnesite content does not exceed $10 \%$. A few samples contained up to $100 \%$ magnesite occur at the surface of the North Playa (probably washed out sediments) and up to $40 \%$ in the South Playa at about 40-50 cm depth. Based on these results, there is no clear evidence to support a trend towards increasing magnesite with depth due to diagenesis, as found in some Mg-carbonate deposits of Kozani (Stamatakis 1995). Detrital minerals such as feldspars and quartz occur close to the sandy glacial substrate. Ca- (calcite, aragonite) or Ca-Mg- carbonate minerals (dolomite, huntite) were not detected in the lacustrine deposits, although minor aragonite is present in crack fills and as surficial crystals, and calcite is present in the travertines.

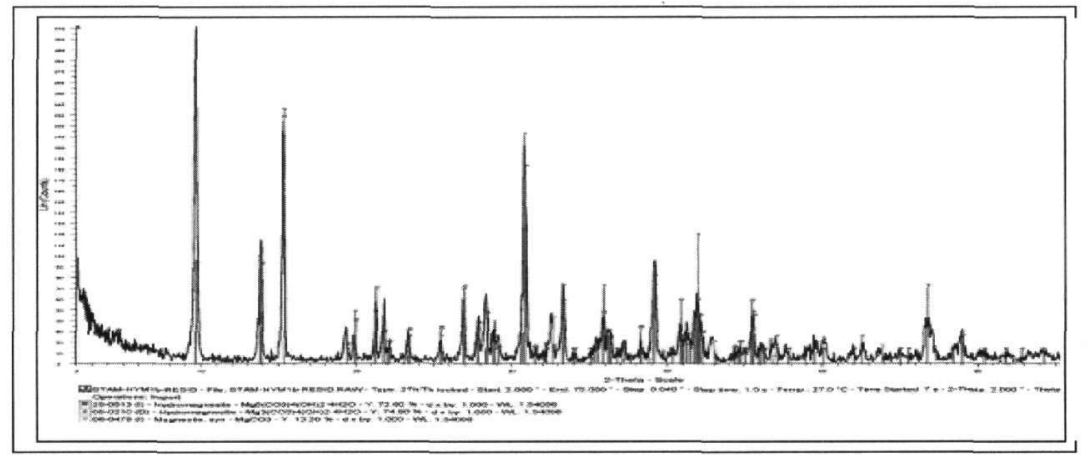

Figure 5 - The XRD pattern of the bulk sample Can-2. The amount of magnesite is $\sim 5 \%$, the rest being hydromagnesite

\subsection{Bulk Chemical analysis (wet chemical analysis)}

As shown in Table 1, the two bulk samples and representative samples of both the North and South playas at Atlin are composed almost entirely of magnesium compounds. The very low iron content of the samples reflects their exceptionally white colour. Other playa lakes in the Cariboo Plateau to the south host sulphates along with hydromagnesite (Renaut and Stead 1990, Renaut 1993), but soluble sulphates and chlorides are negligible in the Atlin hydromagnesite.

\subsection{Whiteness}

Most samples have exceptionally good whiteness that exceeds $90 \%$. The lowest whiteness value among the samples presented in Table 2 is for the surface sample ay site 9 of the North Playa, which has the highest amount of detrital impurities that increase the total amount of $\mathrm{SiO}_{2}$ and $\mathrm{CaO}$. Currently commercial samples of hydromagnesite/huntite and/or brucite mixtures have whiteness values $>95 \%$. The lacustrine $\mathrm{Mg}$-carbonates at Atlin, like the Mg-rich commercial grade carbonates of Kozani, have a high whiteness value, which is a key physical parameter for the utilization of the deposits. The samples collected near the lake margins and the groundwater seepages show poor whiteness presumably because of the presence of coloured aragonite and detrital minerals. Most of the samples collected near the contact of the hydromagnesite beds with 
the sandy substrate also show poor whiteness, because of the contamination of the white material with the grey-green altered products of the substrate and/or the glacial deposits.

\subsection{SSA [specific surface area analysis]}

The SSA of representative Atlin samples, as well as of some commercial samples, was measured. The results are shown in Table 2.

Table 1 - Major element analysis of representative hydromagnesite-magnesite samples of Atlin deposits

\begin{tabular}{|c|c|c|c|c|c|c|}
\hline Sample & $\begin{array}{l}\text { Can-1 } \\
\text { [bulk] }\end{array}$ & $\begin{array}{l}\text { Can-2 } \\
\text { [bulk] }\end{array}$ & $\begin{array}{l}\text { North Playa } \\
\text { site } 9,40 \mathrm{~cm} \\
\text { base }\end{array}$ & $\begin{array}{l}\text { South Playa } \\
\text { site } 32,40 \\
\mathrm{~cm} \text { depth }\end{array}$ & $\begin{array}{l}\text { South } \\
\text { Playa, site } \\
17 \text { surface }\end{array}$ & $\begin{array}{l}\text { South } \\
\text { Playa, site } \\
42 \text { surface }\end{array}$ \\
\hline $\mathrm{SiO}_{2}$ & 0.79 & 0.18 & 4.35 & 0.35 & 0.95 & 0.77 \\
\hline $\mathrm{Al}_{2} \mathrm{O}_{3}$ & 0.12 & 0.10 & 0.20 & BDL & 0.12 & 0.05 \\
\hline $\mathrm{Fe}_{2} \mathrm{O}_{3 \mathrm{t}}$ & 0.05 & 0.04 & 0.05 & BDL & 0.05 & 0.01 \\
\hline $\mathrm{MgO}$ & 44.05 & 42.8 & 43.06 & 44.04 & 43.79 & 43.65 \\
\hline $\mathrm{CaO}$ & 0.09 & 0.78 & 1.27 & 0.12 & 0.13 & 0.40 \\
\hline $\mathrm{Na}_{2} \mathrm{O}$ & 0.03 & 0.26 & BDL & 0.01 & 0.01 & BDL \\
\hline $\mathrm{K}_{2} \mathrm{O}$ & 0.01 & 0.10 & 0.06 & 0.03 & 0.06 & 0.05 \\
\hline $\mathrm{TiO}_{2}$ & BDL & BDL & BDL & BDL & BDL & BDL \\
\hline $\mathrm{MnO}$ & BDL & BDL & 0.01 & BDL & BDL & BDL \\
\hline $\mathrm{P}_{2} \mathrm{O}_{5}$ & $\mathrm{BDL}$ & $\mathrm{BDL}$ & 0.02 & 0.02 & 0.03 & 0.02 \\
\hline LOI & 55.06 & 55.98 & 50.41 & 55.80 & 55.12 & 54.83 \\
\hline TOTAL & 100.20 & 100.04 & $\mathrm{Cc}$ & $\mathbf{V v}$ & $\mathbf{B b}$ & $\mathbf{M m}$ \\
\hline $\mathrm{Cl}^{-} \quad \mathrm{ppm}$ & 118 & 104 & 96 & 88 & 94 & 102 \\
\hline $\mathrm{SO}_{4}{ }^{2-} \mathrm{ppm}$ & 34 & 28 & 22 & 29 & 31 & 16 \\
\hline
\end{tabular}

Table 2 - Physical characteristics of representative Mg-rich samples of Atlin

\begin{tabular}{|l|c|c|c|}
\hline \multicolumn{1}{|c|}{ Sample } & $\begin{array}{c}\text { Mineral content } \\
\%\end{array}$ & $\begin{array}{c}\text { SSA } \\
\mathbf{m}^{2} / \mathbf{g}\end{array}$ & $\begin{array}{c}\text { Whiteness } \\
\text { L }\end{array}$ \\
\hline CAN-1 bulk sample & HYM 95 MG 5 & - & 97.97 \\
\hline CAN-2 bulk sample & HYM 95 MG 5 & - & 97.91 \\
\hline N Playa, site 9 40cm base & HYM 83 MG 10 Others 7 & 20.3 & 94.90 \\
\hline S Playa, site 32 40cm depth & HYM 97 MG 3 & 16.9 & 97.62 \\
\hline S Playa, site 17 surface & HYM 80 MG 20 & 16.9 & 95.51 \\
\hline S Playa, site 42 surface & HYM 88 MG 12 & 13.8 & 97.15 \\
\hline WM Quarry, Kozani, Greece & HYM 40 HU 60 & 22.9 & 98.87 \\
\hline Minelco Quarry, Kozani, Greece & HYM 45 HU 55 & 23.9 & 96.65 \\
\hline Aliakmon R., nuggets, Kozani, & HYM 100 & 12.7 & 98.36 \\
\hline $\begin{array}{l}\text { Explanatory notes: HYM=hydromagnesite, } \text { MG=magnesite, HU=huntite, Others = aragonite, } \\
\text { feldspar, quartz, clay minerals }\end{array}$ & \\
\hline
\end{tabular}

The specific surface area of the Atlin samples is high and comparable with the commercial samples of the hydromagnesite/huntite quarries of the Kozani area, Greece. Despite its comparatively higher amounts of detrital minerals, the sample North Playa, site 9 surface has the 
highest SSA. It is concluded, therefore, that the impurities of the glacial lake floor are very finegrained.

\subsection{Grain size analysis}

The fine nature of the hydromagnesite rocks is clearly shown in Table 3. More than $60 \%$ of the grains are $<4$ microns in size. The extremely fine-grained material is appropriate for certain filler applications.

Table 3 - Grain size analysis of the hydromagnesite-rich bulk samples of Atlin

\begin{tabular}{|c|c|c|c|c|c|c|c|c|c|c|c|c|c|}
\hline \multicolumn{10}{|c|}{ Laser granulometer } \\
\hline & $\mu \mathrm{m}$ & 1.0 & 1.5 & 2.0 & 3.0 & 4.0 & 6.0 & 8.0 & 12.0 & 16.0 & 24.0 & 32.0 & 48.0 \\
\hline Can-1 & & 6.1 & 8.6 & 16.6 & 42.0 & 61.3 & 82.4 & 88.4 & 94.8 & 95.0 & 98.0 & 99.0 & 100.0 \\
\cline { 1 - 9 } & \multirow{2}{*}{ Can-2 } & 6.7 & 9.2 & 17.4 & 43.2 & 62.6 & 83.8 & 89.1 & 95.3 & 95.9 & 98.8 & 99.4 & 100.0 \\
\hline
\end{tabular}

\subsection{Differential Thermal Analysis (DTA) and Differential Scanning Calorimetry (DSC)}

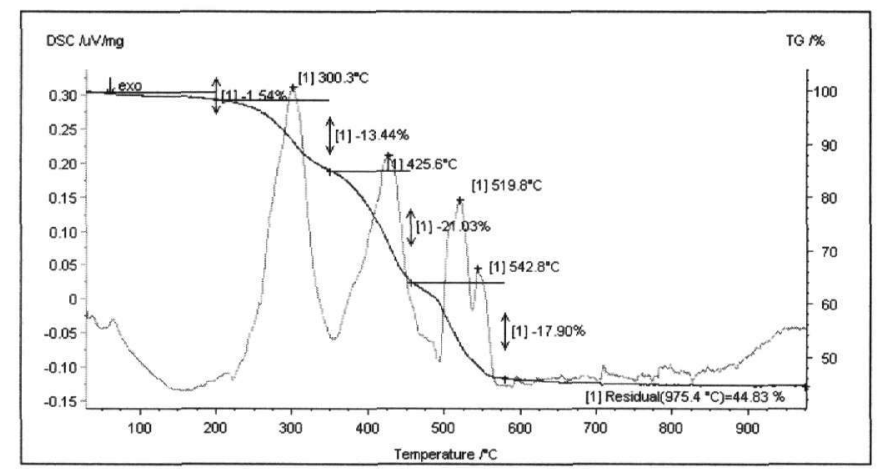

Figure 6 - DTA- DSC analysis without separation of the released gas phases

As shown in Figure 6, there is a gradational loss of gases at $300{ }^{\circ} \mathrm{C}, 425^{\circ} \mathrm{C}$ (almost $35 \%$ of the total weight), and at higher temperatures. The first significant weight losses at around $300{ }^{\circ} \mathrm{C}$ represent the escape of $\mathrm{H}_{2} \mathrm{O}$, whereas at $400{ }^{\circ} \mathrm{C}$ and higher temperature, the escape of $\mathrm{CO}_{2}$ (Stamatakis et al. 2000, Inglethorpe and Stamatakis 2003). No CO is released in an air atmosphere. This temperature range of $\mathrm{H}_{2} \mathrm{O}+\mathrm{CO}_{2}$-loss is desirable for processing of several plastic compounds and for flame-retardant fillers.

\subsection{Scanning Electron Microscopy textural and microprobe analysis}

The SEM images of all analysed samples are similar. A general observation is that rhombohedral sub-microscopic, platy and well-formed crystals of hydromagnesite form closely packed assemblages throughout the rock (Fig. 7). Magnesite, which can also occur as rhombs, is difficult to identify by microprobe analysis, having almost the same $\mathrm{MgO}$ content as hydromagnesite (44$45 \% \mathrm{MgO}$ ). Most hydromagnesite crystals are $<5$ microns in size, in agreement with the grainsize analyses. Aragonite, where present, forms radial aggregates of acicular microcrystals.

\section{Genesis of the deposits}

Hydromagnesite and other Mg-rich carbonates along with aragonite are formed in closed lacustrine basins of Tertiary to Recent age that have high $\mathrm{Mg} / \mathrm{Ca}$ ratio, usually ranging between 30 and 500 (Muller et al. 1972). Laboratory measurements have shown that hydromagnesite and magnesite precipitate directly from $\mathrm{Mg}^{2+}, \mathrm{Na}^{+}$and $\mathrm{HCO}_{3}^{-}$-rich solutions (Alderman 1965). The 
formation of Mg-rich minerals in closed basins is commonly related to an ultramafic and/or dolomitic substrate.

Examples are known from Greece [Kozani], Serbia [Bella Stena, Nevade] and Turkey [Salda Lake], where hydromagnesite/huntite/magnesite plus aragonite, magnesite/dolomite, and hydromagnesite/aragonite assemblages, respectively, are deposited in regions of such bedrock. The main mechanism of their formation is the dissolution of the $\mathrm{Mg}$-silicates in the catchment and the precipitation of $\mathrm{Mg}^{2+}$ in the form of $\mathrm{Mg}$ - and/or $\mathrm{Mg}$-Ca-carbonates in a closed hydrological system (Stamatakis 1995).
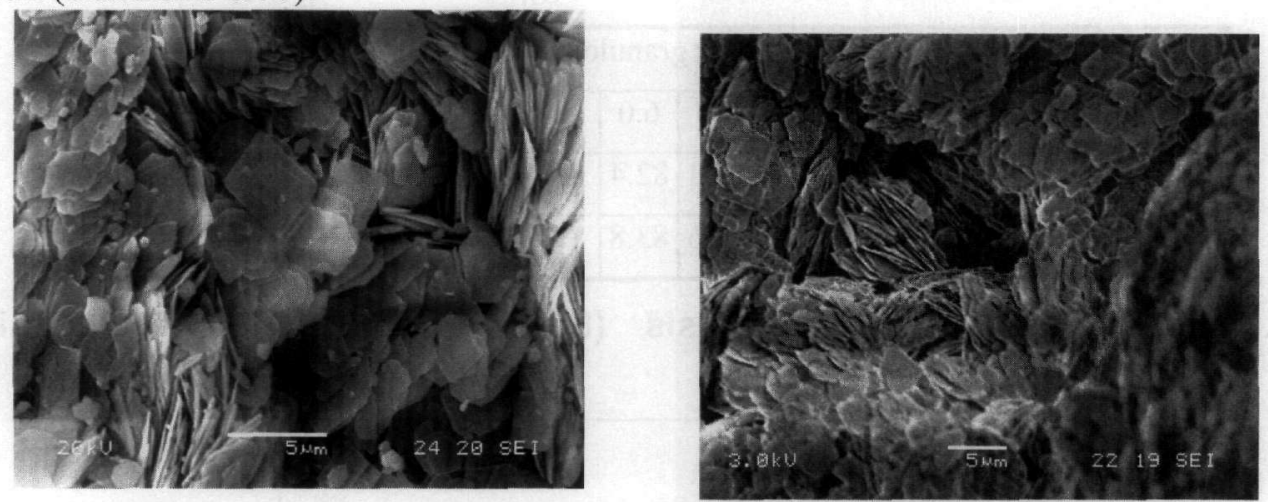

Figure 7 - SEM images of the platy hydromagnesite/magnesite mineral assemblages of the bulk sample Can-2. Even magnesite has platy texture, making almost impossible its distinction from hydromagnesite by SEM-EDS analysis. In the right image, late stage magnesite-hydromagnesite crystals are filling a pore

Table 4 - Water chemistry of Atlin open pools and springs within the hydromagnesite/magnesite masses (all ion measurements and silica in $\mathrm{mg} / \mathrm{L}$ )

\begin{tabular}{|l|c|c|c|c|c|c|c|c|c|c|c|c|c|c|c|}
\hline Sample & $\mathrm{HCO}_{3}{ }^{-}$ & $\mathrm{CO}_{3}{ }^{2-}$ & $\mathrm{Cl}^{-}$ & $\mathrm{OH}^{-}$ & $\mathrm{NO}_{3}{ }^{-}$ & $\mathrm{SO}_{4}{ }^{2-}$ & $\mathrm{Mg}^{2+}$ & $\mathrm{Ca}^{2+}$ & $\mathrm{Na}^{+}$ & $\mathrm{K}^{+}$ & $\mathrm{SiO}_{2}$ & $\mathrm{pH}$ & Alkalinity & Sp. Cond. & Hardness \\
\hline Atlin2 & 4280 & 595 & 11 & $<0.1$ & 1.6 & 140 & 1080 & 6.4 & 106 & 15 & 16 & 8.43 & 4500 & 5070 & 4460 \\
\hline Atlin 3 & 4450 & 598 & 11 & $<0.1$ & 1.6 & 140 & 1090 & 6.6 & 105 & 14 & 21 & 8.44 & 4640 & 5120 & 4500 \\
\hline
\end{tabular}

The Atlin hydromagnesite deposits are clearly post-glacial (Holocene) in age. The dry North Playa carbonates are essentially fossil deposits. Hydromagnesite appears to be actively forming in the wetlands of the northern part of the South Playa, and could be precipitating from shallow groundwater elsewhere in the playa, although this is uncertain. The patchy fossil travertines show that springs, either subaerial or sublacustrine, might have provided alkaline waters to the lakes during the main phase(s) of hydromagnesite precipitation.

Although some hydromagnesite may be inorganic (Muller et al. 1972), recent research has shown that microbes and other organisms can contribute to its precipitation in lakes (Russell et al. 1999). At Atlin, the springs and small ponds that discharge within the hydromagnesite deposits (especially on the South Playa) contain filamentous microbes (mainly cyanobacteria) encrusted with Mg-carbonates (Figs 8a, b). It appears, therefore, that microbes can potentially mediate some precipitation of hydromagnesite. Renaut (1993) showed that cyanobacteria might have contributed to some hydromagnesite formation in the Cariboo lakes. More recently, Power et al. (2005) have suggested that cyanobacteria might catalyze precipitation of hydromagnesite in the wetlands at Atlin. They showed that hydromagnesite precipitates subaqueously, whereas nesquehonite is formed abiotically as surficial crusts. On the other hand, the hydrochemistry of the springs and lake at Atlin is characterized by high $\mathrm{Mg}^{2+}$ and $\mathrm{HCO}_{3}{ }^{-}$and low $\mathrm{Ca}^{2+}$ content (Table 4), and an $\mathrm{Mg} / \mathrm{Ca}$ ratio of $150-180$, which is high enough for inorganic precipitation of hydromagnesite and magnesite. 

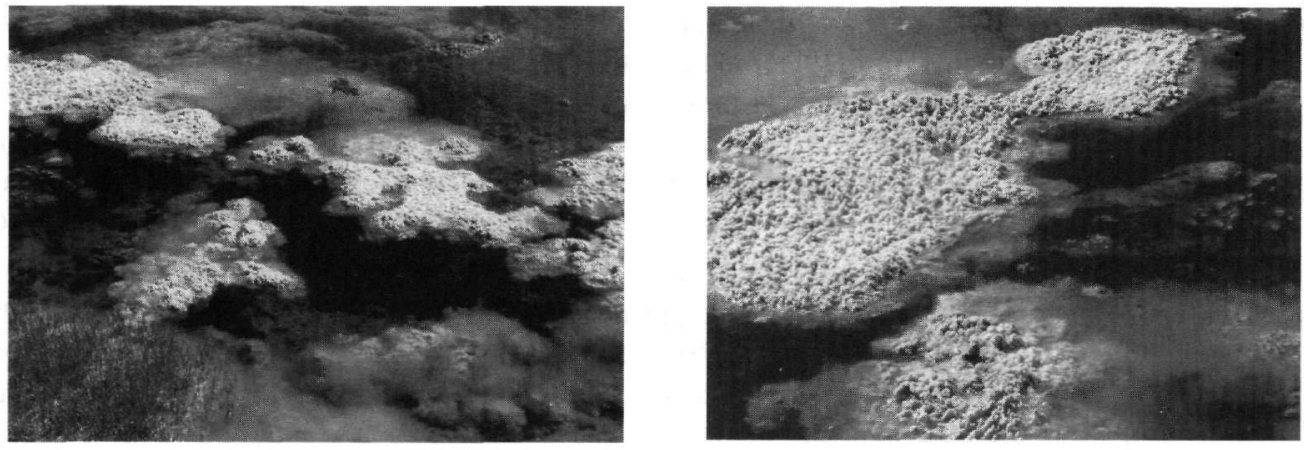

Figure 8-a \& b: Living microbialites in springs of the central part of South Playa Lake, Atlin. Note the white carbonates formed above the lake level, on the organic substrate

In addition, the role of $\mathrm{CO}_{2}$-rich fluid phases in listwanite formation (a carbonate-altered serpentinite) is well documented in the Atlin bedrock (Hansen et al. 2005). Similar bicarbonaterich solutions could have promoted inorganic sedimentation of hydromagnesite in the Atlin playas. It is likely, therefore, that the $\mathrm{Mg}$-carbonates of Atlin originated by a combination of biological (microbially mediated) and chemical processes. Evaporative concentration, $\mathrm{CO}_{2}$-degassing, and microbial mediation together might have induced precipitation of the $\mathrm{Mg}$-carbonates from $\mathrm{Mg}$ enriched fluids delivered to the closed basins by runoff and sublacustrine (?) springs.

\section{Conclusions and Industrial Potential}

- The Holocene hydromagnesite deposits at Atlin are mainly fossil deposits that originated both by abiotic and biotic (microbial) processes. Mg-rich waters, fed by runoff and groundwaters (subaerial and sublacustrine springs) flowed into closed basins that underwent evaporative concentration, precipitating $\mathrm{Mg}$-carbonates with some Cacarbonates (travertines) from less evolved waters near spring vents. Minor Mg-carbonates, some of which are likely biomediated by cyanobacteria, are precipitating today from $\mathrm{Mg}$ enriched groundwaters at springs and in alkaline wetlands.

- The Atlin hydromagnesite samples are composed mainly of hydromagnesite with minor amounts of magnesite. Although hard, angular magnesite grains are impurities in the commercial-grade Greek deposits (hydromagnesite-huntite), the magnesite in the Atlin deposits is very fine-grained, soft and platy, with similar textural properties to hydromagnesite.

- The iron, chloride and sulphate contents of the Atlin hydromagnesite are negligible.

- The whiteness of the Atlin samples is sufficient for exploitation, and comparable to the commercial hydromagnesite-bearing rocks of northern Greece.

- The shape and grain size of the samples are comparable to commercial samples and appropriate for use as white fillers.

- The DTA-DSC patterns and temperatures of $\mathrm{H}_{2} \mathrm{O}$ - and $\mathrm{CO}_{2}$-release are similar to hydromagnesite-bearing samples that are exploited commercially elsewhere.

- The mineralogical composition of the Atlin samples, their behaviour during thermal decomposition, and their chemical and physical properties make them suitable for use as white fillers for special applications, especially as flame-retardants.

- The magnesite content is low and despite its inert properties as a flame-retardant (losing $\mathrm{CO}_{2}$ at temperatures $>400{ }^{\circ} \mathrm{C}$ ), it does not affect the overall quality of the deposit because the currently accepted upper-value in commercial products is $\sim 10 \%$. If the material is mixed with pure huntite and/or brucite, the presence of magnesite will be acceptably low. 
- The estimated reserves of the hydromagnesite ore bodies are $\sim 110,000$ tons (Grant 1987). Our field measurements on the geometry of the hydromagnesite substrate suggest that this amount is overestimated, because at most sites the total thickness of the "pure" material is $<40 \mathrm{~cm}$. In addition, because of weathering, the surficial material must be removed due to its intermixing with residual deposits (gravel from basement rock, aragonite accumulations, and organics). A systematic study using shallow boreholes is needed for a true estimate of the reserves.

- Two more factors must be considered: (1) because fine-grained hydromagnesite adsorbs water and can expand ("cauliflowers"), the reported thickness is apparent and this must be taken into consideration in a more precise calculation of the reserves, and (2) the water adsorption of the hydromagnesite material is $>50 \%$ of its total weight, so in the event of exploitation, the extracted material must be dried before shipment.

- If the deposits are considered economic for development, a techno-economic assessment and a study of flame-retardant marketing in the western Canada and the USA will provide key parameters for the selection of the location of any processing plant for raw materials and the manufacturing of end-products.

- The end products can be based on single hydromagnesite mineral, or on mixtures of hydromagnesite with huntite and/or brucite imported from abroad.

\section{Acknowledgements}

This paper presents some of the results obtained during a two-year Greek-Canadian co-operation project entitled The potential of white mg-rich carbonates from Kozani, Greece and British Columbia, Canada for use as non-toxic flame-retardants. The authors thank the General Secretary of Research \& Development [GSRT] of Greece, NSERC (Grant RGPIN-629 to RWR), and the University of Saskatchewan, Canada, for their cooperation and financial supporting of the project. Thanks are also expressed to Mr. Sakis Chatzinikolaou of MINELCO Hellas and Mr. Cliff Briggs of MINELCO SA for their help with chemical analysis, and specific surface area analysis of several Atlin (BC) and Kozani (Greece) samples, and Mr. J. Havelas of TITAN Cement Company SA for help with the grain size analysis.

\section{Literature}

Alderman, A.R., 1965. Dolomite sediments and their environment in the south-east of South Australia, Geochim. Cosmochim. Acta, 9, 1355-1365.

Aitken, J.D., 1959. Atlin map-area British Columbia, Geological Survey of Canada, Memoir 307 $(104 \mathrm{~N}), 89 \mathrm{pp}$.

Ashley, R.J., and Rothon, R.N., 1991. Use of magnesium hydroxide as a flame retardant filler. In: Griffiths J. Editor, Mineral Fillers in Polymers, IMIL publication, 24-26pp.

Decker De, M., 1999. White minerals in plastics, Industrial Minerals No 384, 59-65.

Grant, B., 1987. Magnesite, brucite and hydromagnesite occurrences in British Columbia, Open File Report of the British Columbia Geological Survey Branch No 1987-13.

Hansen, L.D., Dipple, G.M., Gordon, T.M., and Kellet, D.A., 2005. Carbonated serpentinite (listwanite) at Atlin, British Columbia: a geological analogue to carbon dioxide sequestration, The Canadian Mineralogist, 43, 225-239.

Inglethorpe, S.D., and Stamatakis, M.G., 2003. Thermal decomposition of natural mixtures of hydromagnesite and huntite from Kozani, Northern Greece, Mineral Wealth, $\mathrm{N}^{\circ}$ 126, 7-18. 
Jones, B., Renaut, R.W., Rosen, M.R., and Ansdell, K.M., 2002. Coniform stromatolites from geothermal systems, North Island, New Zealand, Palaios, 17, 84-103.

Kirschbaum, G., 1999. Overview of mineral flame retardants markets, Minerals in Compounding '99, 8-10 November 1999, Geneva, Switzerland, 11pp.

Loughbrough, R., 1991. Flame retardants. Legislation fires markets, Industrial Minerals No 284, $35-43$.

Muller, G., Irion, G., and Forstner, U., 1972. Formation and diagenesis of inorganic Ca-Mg carbonates in the lacustrine environment, Naturwissenschaften, 59, 158-164.

Power, I., Dipple, G.M., and Southam, G., 2005. Biomineralization of hydromagnesite and its application in carbon dioxide sequestration, American Geophysical Union Fall Meeting, San Francisco, California, December 2005, abstract.

Renaut, R.W., and Stead, D., 1990. Recent magnesite-hydromagnesite sedimentation in playa basins of the Cariboo Plateau, British Columbia, British Columbia Geological Survey Branch, Geological Fieldwork 1990, Paper 1991-1, 279-288pp.

Renaut, R.W., 1993. Morphology, distribution and preservation potential of microbial mats in the hydromagnesite-magnesite playas of the Cariboo Plateau, British Columbia, Canada, Hydrobiologia, 267, 75-98.

Rothon, R.N., 1994. Mineral requirements for flame-retardants, Industrial Minerals $\mathrm{N}^{\mathrm{o}} 327$, December 1994.

Rothon, R.N., 1995. Effects of particulate fillers on flame retardant properties of composites. Chapter 6. In R.N. Rothon (ed.), Particulate-filled polymer composites, Longman Scientific \& Technical. 207-234pp.

Rothon, R.N., 2003 Mineral fillers in thermoplastics-I: Filler manufacture and characterization, Springer-Verlag, Heidelberg, p. 67-107.

Russell, M.J., Ingham, J.K., Zedef, V., Maktav, D., Sunar, F., Hall, A.J., and Fallick, A.E., 1999. Search for signs of ancient life on Mars: expectations from hydromagnesite microbialites, Salda Lake, Turkey, The Journal of the Geological Society, 156, 869-888.

Schmidt, R., 1998. In the line of fire: Flame retardants overview, Proceedings of "Minerals in Compounding” Neuss, Germany 29 June 1998, IMIL Publ., 39-41pp.

Simandl, G.J., Simandl, J., and Debreceni, A., 2001. British Columbia Hydromagnesite-Magnesite Resources: Potential Flame Retardant Material, Geological Fieldwork 2000, Paper 2001-1, 327-336pp.

Simandl, G.J., 2003. Green minerals and market changes driven by environmental regulations, $16^{\text {th }}$ Industrial Minerals International Congress, Proceedings, 153-161pp.

Stamatakis, M.G., 1995. Huntite-hydromagnesite assemblages - the Greek snow-white filler and extender, Inst. Mining and Metallurgy, Transactions B, V. 104, B179-B186pp.

Stamatakis, M.G, Inglethorpe, S.D.J., and Karkanas, P., 2000. White Magnesium mineral deposits of Kozani Basin and their potential as fire-retardants, $1^{\text {st }}$ Congress of the Greek Committee of Economic Geology, Geochemistry and Mineralogy, Greek Geological Society, V. 1. 413-426pp. 